\title{
Dinamik geometri yazılımı etkinliklerinin öğrenci performansları bağlamında incelenmesi: analitik düzlemde doğru denklemleri*
}

\author{
Ali DELÍCE ${ }^{* *}$ \\ Gökhan KARAASLAN***
}

\section{Özet}

$\mathrm{Bu}$ çalışmanın amacı, doğru denklemleri konusuna yönelik hazırlanan etkinliklerin öğrenci performanslarına etkisini araştırmak ve öğretmenlerin hazırlanan etkinlikler hakkında görüşlerini ortaya çıkarmaktır. Çalışmada karma yöntem yaklaşımı benimsenmiş olup nitel araştırma desenlerinden eylem araştırması kullanılmıştır. Araştırma verileri, Geocebir yazılımı ile hazırlanan etkinlikler, doğru denklemleri performans testi ve yarı yapılandırılmış görüşme kullanılarak toplanmıştır. Öğretim süreci içinde yer alan öğrenciler ile hazırlanan etkinlikler hakkında görüşleri ortaya çıkarılan öğretmenler amaçlı örnekleme yöntemi kullanılarak araştırmanın çalışma grubu olarak belirlenmiştir. Doğru denklemleri konusunun öğretimi için Burdur ilinde bir meslek lisesinde öğrenim gören 36 lise 9. sinıf öğrencisi ve mezun olduğu fakülte ve meslek deneyimleri değişkenleri dikkate alınan öğretmenler araştırmanın çalışma grubunu oluşturmuşlardır. Elde edilen nitel veriler, betimsel istatistik kullanılarak analiz edilmiş, görüşmeler ise bulguları gerekçelendirmek ve tartışmak amaçlı destekleyici veri olarak kullanılmıştır. Performans Testi sonuçlarına göre Geocebir yazılımı yardımıyla hazırlanan etkinliklerle çalışan öğrencilerin başarı düzeylerinin öğretim programında yer alan etkinliklerle çalışan öğrencilere göre daha yüksek olduğu bulunmuştur. Etkinliklerde bilgilerin doğrudan verilmemesi ve öğrencilerin bilgiyi oluşturma çabası öğrencilerin çözüm süreçlerine yansımıştır. Hazırlanan etkinlikler öğretmenler tarafından öğretim programına uygun bulunmuş ve öğrencilerin konuyu öğrenmelerinde faydalı olacağı ifade edilmiştir. Bu çalışma analitik düzlemde doğru denklemleri konusu temel alınarak etkinlik ve teknoloji karma yaklaşım kullanımının yeni programın felsefesine uygunluğu, problem çözme sürecine pozitif yansıması, öğretmenlerce benimsenmesi ve örnek teşkil etmesi yönüyle öğretim sürecine katkısını ortaya çıkarmıştır.

Anahtar kelimeler: Teknoloji destekli matematik eğitimi, Geocebir yazılımı, doğru denklemleri

* I. Türk Bilgisayar ve Matematik Eğitimi Sempozyumu’nda (20-22 Haziran 2013 Trabzon - Türkiye) sunulan bu çalışma, Marmara Üniversitesi Bilimsel Araştırma Projeleri Birimi tarafından desteklenen EGT-C-TLP-110412-0121 projesinden elde edilmiştir.

** Doç. Dr., Marmara Üniversitesi, Atatürk Eğitim Fakültesi, OFMA Bölümü, alidelice@marmara.edu.tr

*** Öğretmen, Burdur Çayboyu Mesleki ve Teknik Anadolu Lisesi, gkaraaslan@hacettepe.edu.tr 


\title{
Investigation of the effects of the dynamic geometry software tasks on students' performance: lineer equations
}

\begin{abstract}
Purpose of this study is to investigate the effects of tasks about lineare quations on students' performance and find out the teachers' opinions about them. This study which has qualitative paradigm also utilizes action research design. Tasks prepared on Geogebra software, performance test of linearequations, semi-structured interview are the techniques used to collect data. Purposive sampling is used as a sampling method to select students for the tests and teachers for the semistructured interview. For teaching of the lineare quations, 36 of the $9^{\text {th }}$ grade students have been chosen from a vocational high school in Burdur. Six different teachers have been identified with respect to the parameters of graduation, faculty and work experience. Descriptive statistics is utilized to analyze qualitative data and the data obtained from the semi-structured interviews was used to discuss the findings and supporting data to bolster the arguments. Performance test has revealed that students who completed tasks prepared by the Geogebra software were more successful than the students who completed the tasks defined in the curriculum. Indirect information provided in the tasks and the way students construct meaning through indirect information affected the students' performance and eventually their solution process. It was stated by the teachers that the tasks are in accordance with the educational program and are helpful to students in learning the topics. In this study using a mix of the tasks and technology to teach linear equations revealed a contribution to teaching and learning process in terms of the new curriculum paradigm, a positive reflection on the problem solving proces, teachers' adoption of this practice.
\end{abstract}

Keywords: Technology-supported mathematics education, Geogebra, linear equations

\section{Giriş}

Bilgisayar teknolojilerindeki gelişmeler, öğrenme-öğretme sürecinde öğrencilerin kavramları anlama düzeylerini arttırıcı birçok yeni olanaklar sunmaktadır. Özellikle matematik ve geometri gibi soyut kavram ve ilişkilerin ele alındığı derslerde bu kavram ve ilişkilerin somutlaştırılmasında bilgisayar destekli öğretim (BDÖ) önem kazanmaktadır (Karakırık ve Aydın, 2011, s. 20-21). Bilgisayarın, etkileşimli etkinliklerle aktif öğrenmenin meydana geldiği bir ortam olarak kullanılması esasına dayanan (MEB, 2011a, s. 24) BDÖ, materyalleri ya da bilgiyi en iyi şekilde kullanmada öğrenciye ve öğretim sürecine yardım amacını güder (Uşun, 2004, s. 43). Bilgisayar teknolojisinde yaşanan hızlı gelişmelerin geometri öğretimindeki yansımaları olan dinamik geometri yazılımları, matematik eğitiminin bu amaçlara ulaşabilmesi için umut vaat etmektedirler (Güven ve Karataş, 2003). Geometri, görselliğin fazla olması ve akılda canlandırmanın zor olması nedeniyle matematiğe göre daha karmaşık bir alan haline gelmiştir (Karakuş, 2008, s. 19). Geometrinin karmaşıklığını gidererek somut ve kolay öğrenilir hale getirmek için çeşitli cisim, şekil, somut araçlardan ve görsel materyallerden yararlanmak gerekliliği vurgulanmaktadır (Baykul, 2009, s. 358). Bilgisayar teknolojisi, sahip olduğu soyut kavramları görselleştirme özelliği 
sayesinde bu materyallerin başında yer almaktadır.

Bilgisayar destekli geometri öğretiminin öğrenme-öğretme süreçlerindeki başarısı çeşitli değişkenlere bağlı olmakla birlikte, bu yöntemin başarısında, hedef ve amaçlara uygun yazılımların kullanılması oldukça önemlidir (Uşun, 2004, s. 43). Uzmanlar tarafından çeşitli çalışmalarla da geçerliği ve güvenirliği sağlanmış, öğretim ve öğrenim sürecinde, kavramların yapılandırılmasında, örnek çözüm ve özellikle etkinliklerde kullanılan ve kullanılması önerilen irili ufaklı birçok yazılım vardır. Bunlardan en bilinenleri ve sık kullanılanları arasında Geocebir yazılımının olduğu söylenebilir. Geocebir, geometri, cebir ve analizi birleştiren dinamik bir matematik ve geometri yazılımıdır. Geocebir'i diğer yazılımlardan ayıran özelliklerin başında hem cebir hem de geometriyi dinamik olarak beraberce ele alması yer alır (Doğan, 2011, s. 97). Cebirin ifade edildiği cebir penceresi ve geometrinin ifade edildiği grafik penceresi yardımılla geometri ve cebir arasındaki ilişkilerin oluşturulması ve gözlenmesi sağlanabilir (Hohenwarter ve Jones, 2007). Şekil 1 incelendiğinde, Geocebir yazılımının grafik ve cebir penceresinin aynı çalışma sayfasında yer aldığ görülmektedir. Cebir penceresindeki bir ifade grafik penceresindeki bir nesneye karşıllk gelir veya tersi işlemler gerçekleştirilebilir ki bu durumda cebir ve grafik temsil arasındaki ilişkinin çift taraflı anlaşılmasına yardımcı olur (Hohenwarter ve Hohenwarter, 2011).

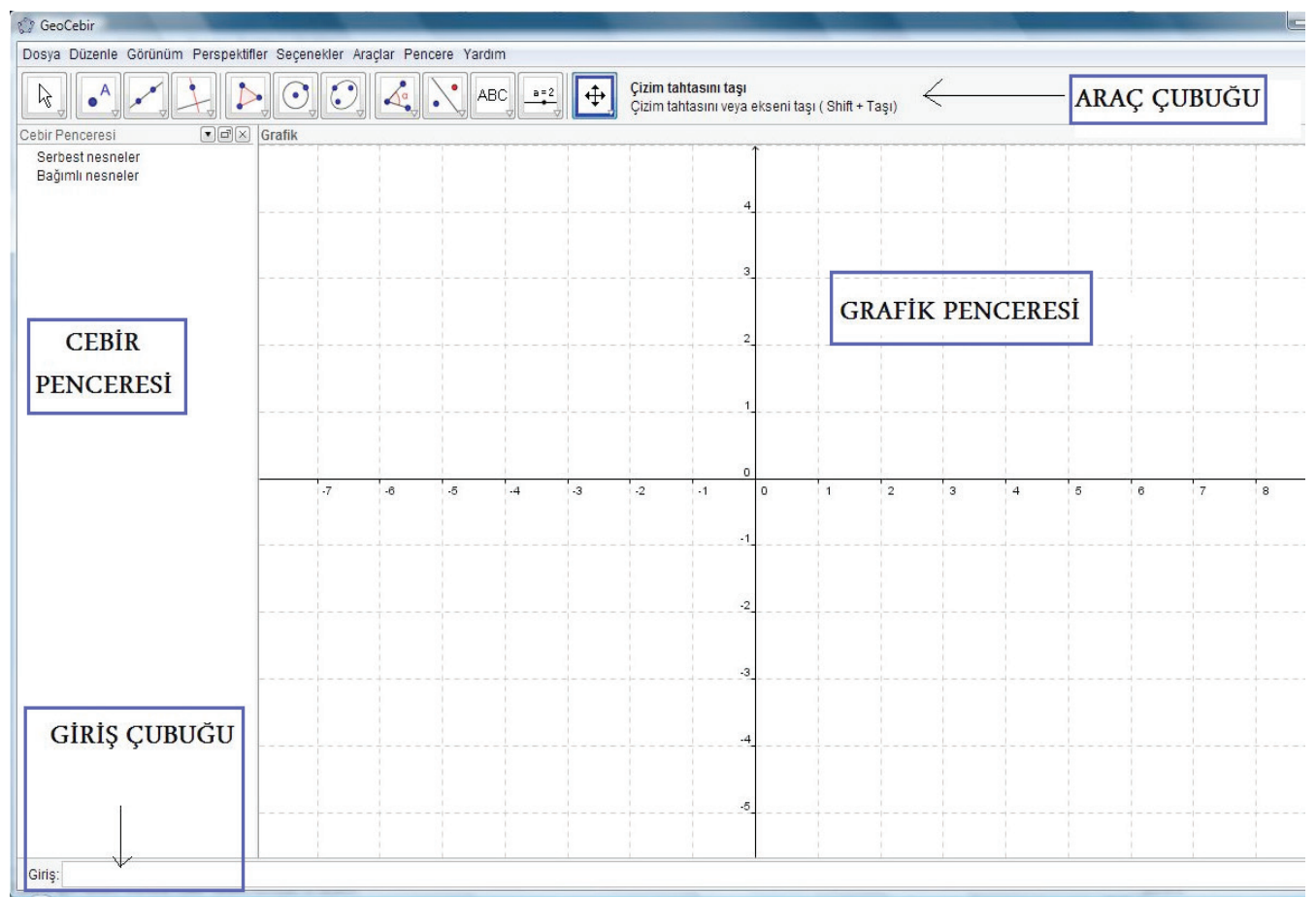

Şekil I. Geocebir yazılımının kullanıcı arayüzü 
Güncellenen Matematik öğretim programında yazılımların çoklu temsillere (sayısal, cebir, grafik) olanak sağlayarak öğrencilerin matematiksel durumları daha iyi anlamalarına yardımcı olduğu ifade edilmektedir (MEB, 2013, s. XI). Geocebir yazılımı bu çoklu temsillere aynı çalışma sayfasında imkân sağlamaktadır. Kullanıcılar, Geocebir yazılımındaki sürgü aracını kullanarak ya da nesnelerin yerini değiştirerek nesneler arasındaki bağıntıları öğrenebilmektedir (Dikovic, 2009). Geocebir yazılımının diğer bir önemli özelliği ise ücretsiz olup yazılımın kendisinin ve kullanım kılavuzunun Türkçeye çevrilmiş olmasıdır. Bu iki özellik yazılımın bilimsel çalışmalarda kullanılmasını-yaygınlaştırmıştır.

Etkinlik; öğrenci merkezli etkin öğrenmeyi esas alan, bireyin kendi bilgilerini yapılandırmasında ve sonrasında bu bilgileri yeni durumlara uygulanmasına firsat veren, günlük yaşamla ilişkili ve dikkat çekici, farklı düşünme ve yaratıcılık isteyen, yapılandırmacı öğrenme yaklaşımı doğrultusunda geliştirilen, öğrencilerin iletişim kurmaları yoluyla kavramları anlamalarını sağlayan bir yapıdır (Uğurel ve Bukova-Güzel, 2010). Matematiksel etkinlikler, öğrencinin öğretim sürecine etkin bir şekilde katılımını sağlayarak öğrencilere, matematiğin temel kavramları üzerinde düşünmelerini ve genelleme yapmalarını sağlayarak, matematiksel çlkarımlar ve hesap yapmalarına imkân verir (Henningsen ve Stein, 1997; akt. Kerpiç ve Bozkurt, 2011). Öğrencilere iyi tasarlanmış etkinliklerin doğru ve yerinde uygulanması durumunda öğrenmenin daha kalıcı ve anlamlı olabileceği söylenebilir (Kerpiç ve Bozkurt, 2011).

Bir araştırmada ya da ders planı için, etkinlikler hazırlanırken keyfi hazırlamaktansa hem öğretim programındaki (MEB, 2011a, s. 21-22) etkinlik tasarlama süreci ile ilgili uyarılar hem de Özmantar ve Bingölbali’nin (2009, s. 322) ifade ettiği etkinliğin tasarlanması sırasında dikkat edilmesi gereken ilkeler (etkinliğin amacı, sınıf yönetimi, etkinliğin birden fazla başlangıç noktasına sahip olması, kullanılacak araçlar, öğretmen ve öğrenci rolleri, öğrencilerin ön bilgileri, öğrenci zorluk ve yanılgıları, ölçme değerlendirme) göz önünde bulundurulmalıdır.

Yapılandırmacı yaklaşımı temel alan öğretim programlarında etkinlikler merkezi bir yere ve öneme sahiptir (Uğurel ve Bukova-Güzel, 2010). Bu çalışmada da, doğru denklemleri konusuna yönelik öğretmen odaklı öğretme etkinlikleri yerine öğrenci odaklı ve derse aktif katılımı sağlayan öğrenme etkinlikleri hazırlanmıştır. Her etkinlik aynı yaklaşımla tasarlanmak istenilse de her konuda her zaman güzel ve ilgi çekici etkinlik geliştirmek kolay değildir (Ersoy, 2006, s. 33). Bu nedenle bu araştırma kapsamında Geocebir yazılımı ile hazırlanan etkinliklerin süreci ve ürünü ile öğretmenlere bir kaynak olacağı düşünülmektedir.

Geocebir yazılımı ile fonksiyon temelli matematik konuları (fonksiyon, trigonometri, türev, integral), denklemler, vektörler, dönüşüm geometrisi ve analitik geometri konularına yönelik etkinlikler hazırlanabilir (Doğan, 2011, s. 100-101). Analitik geometri, cebir ve geometrinin iyi bir uygulamasıdır ve en önemli özelliği, bir cebirsel denklemi bir geometrik şekille ilişkilendirebilmesidir (Erüs, 2007, s. 39). Öğrencilerin cebir ve geometri arasındaki ilişkiyi daha iyi kurmalarına yardımcı olmak amacı ile bu çalışmada doğru denklemleri, doğrunun eğimi ve birbirine göre durumları alt konularından oluşan analitik düzlemde doğru denklemleri konusu seçilmiştir. 


\section{Araştırmanın amacı}

Doğru denklemleri konusunda, öğrencilerin sınıf ortamında aktif katılımcı olmasını sağlayacak, bilgisayarla ve akranlarıyla etkileşimlerinden kendi bilgilerini oluşturmalarına imkân sağlayacak etkinlikler hazırlamak bu çalışmanın amaçlarından biridir. Araştırmanın diğer bir amacı ise hazırlanan etkinliklerle gerçekleştirilen öğretim sürecinin öğrencilerin doğru denklemleri konusundaki performanslarına etkisini belirlemektir. Yazılımın grafikleri hızlı ve pratik çizebilmesi, birden fazla gösterimi aynı anda göstermesi, denklemlerin ve koordinatların giriş çubuğuna direkt olarak yazılabilmesi gibi özellikleri göz önünde bulundurulduğunda doğru denklemleri konusunun öğretimine katkı sağlayacağı düşünüldüğünden bu çalışmada Geocebir tercih edilmiştir.

BDÖ’ye yönelik yapılan çalışmalarda öğretmenlerin teknolojiyi kullanarak hazırlayacağı ders planları yapmaları için yeterli kaynak olmadığı (Baki, 1996) ifade edildiği gibi öğretmenlerin de çağdaş öğrenme kuramlarına dayalı olarak materyal geliştirme ve öğrenme ortamı hazırlama konusunda yeterli olmadığı ortaya koyulmaktadır (Akdeniz, Yiğit ve Kurt, 2002). BDÖ’yü yaygın hale getirmek için, öğretmenlere daha fazla hizmet içi eğitim olanağının sağlanması gerektiği ve örnek ders anlatımlarının sunulması gerektiği önerilmektedir (Yenilmez ve Karakuş, 2007). $\mathrm{Bu}$ çalışma kapsamında hazırlanan etkinlikler öğretmenlere sunularak hem öğretmenlerin hazırlanan etkinlikler hakkında görüşlerini ortaya koymak hem de bilgisayar destekli öğrenme ortamı hazırlama konusunda örneklerin tanıtılması bu araştırmanın bir diğer amacıdır.

Sonuç olarak araştırma soruları aşağıdaki gibi şekillenmiştir:

- “Analitik düzlemde doğru denklemleri” konusuna yönelik Geocebir yazılımı yardımıyla hazırlanan etkinliklerle öğrenim gören öğrencilerin performansları ile öğretim programındaki etkinliklerle öğrenim gören öğrencilerin performansları nasıldır?

- Öğretmenlerin, Geocebir yazılımı yardımıyla hazırlanan etkinlikler hakkındaki görüşleri nelerdir?

\section{Yöntem}

Bilimsel bir araştırmanın yaklaşımını, bu araştırmaya yön veren, araştırmanın niçin ve nasıl yapıldığını gösteren felsefi ve pratik açıklamalar, destekleyiciler ve süreçler oluşturmaktadır (Ekiz, 2009, s. 7). Bu çalışmada öğretim süreci içerisinde Geocebir yazılımı yardımıyla hazırlanan etkinliklerin öğrencilerin geometri derslerindeki performanslarına etkisi derinlemesine incelendiğinden nitel paradigmaya sahip olup doğal ortamda gerçekleştiği için sosyal bilimlerin doğasına uygun olarak yorumlayıcı yaklaşıma sahiptir.

Eğitim araştırmalarında kullanılan yöntem, veri toplama ve elde edilen verileri analiz etme yöntemleri bakımından nitel ve nicel yaklaşımlara sahip olabilir ve özellikle de nitel araştırmalarda araştırmacı incelediği durumun içerisinde yer alır. Bu araştırmada, eylem araştırması, araştırmanın modeli olarak belirlenmiştir. Eylem araştırması, bizzat uygulamanın içinde olan bir 
uygulayıcının doğrudan kendisinin ya da bir araştırmacı ile birlikte gerçekleştirdiği ve uygulama sürecine ilişkin problemlerin ortaya çıkarılması ya da bir problemi anlama ve çözmeye yönelik sistematik veri toplamayı ve analiz etmeyi içeren bir araştırma modelidir (Yıldırım ve Şimşek, s. 295). Bu çalışmada araştırmacilardan biri öğretim sürecinde öğretmen olarak görev alarak öğretim yöntemini zenginleştirecek etkinlikleri uygulamakta ve bu süreci değerlendirmektedir. Eylem araştırması nitel bir araştırma yöntemi olmakla birlikte eylem araştırmalarında nicel veri toplama yöntemleri de kullanılmaktadır (Çepni, 2010; Yıldırım ve Şimşek, 2008).

Eğitim araştırmalarında, özellikle öğretmenlerin yürüttüğü araştırmalarda, nitel ve nicel araştırma yöntemlerinin birlikte kullanılması görüşü önerilmektedir (Çepni, 2010, s. 33). $\mathrm{Bu}$ görüşün sebebi bilgiye bakış açlları ve veri toplama yolları birbirinden farklılık gösteren iki yöntemin birlikte kullanılması, birbirini tamamlamakta ve birbirinin zayıf yönlerini kapatmaktadır (Dey, 1993). Bu araştırmada "yorumlayıcı" paradigmaya göre biçimlenen nitel araştırma yöntemleri ağırlıklı olmak üzere nitel ve nicel yöntemlerin birlikte kullanılacağı karma yaklaşım benimsenmiştir.

\section{Örneklem}

Eylem araştırmalarında zengin bir içeriğe sahip olduğu düşünülen durumların derinlemesine çalışılmasına imkân tanıyan amaçlı örnekleme yöntemi kullanılır. Bu çalışmada öğretim süreci içinde yer alan öğrenciler ile hazırlanan etkinlikler hakkında görüşleri ortaya çıkarılan öğretmenler çalı̧ma grubu olarak belirlenirken amaçlı örnekleme yönteminin iki farklı tekniği kullanılmıştır. Doğru denklemleri konusunun öğretimi için Burdur ilinin bir meslek lisesinde öğrenim gören 36 lise 9.sınıf öğrencisi belirlenirken kolay ulaşılabilir durum örneklemesi tekniği kullanılmıştır. Eylem araştırması deseninin kullanıldığı bu çalışmada öğretim sürecini yürüten araştırmacı Burdur ilinde bir meslek lisesinde görev yapan Matematik öğretmenidir. Araştırmacının öğretim yılı içerisinde görev yaptığı okuldaki öğrenciler dışında başka bir çalışma grubu belirleyebilmesi mümkün olmadığından kolay ulaşılabilir durum örneklemesi tekniği kullanılmıştır.

Öğretmenler belirlenirken hazırlanan-etkinlikler kapsamında çeşitlilik gösteren durumlar arasında herhangi ortak ya da paylaşılan olguların olup olmadığını bulmaya çalışmak ve bu çeşitliliğe göre problemin farklı boyutlarını ortaya çıkarabilmek için amaçlı örnekleme yöntemlerinden maksimum çeşitlilik örneklemesi tekniği kullanılmıştır. Öğretmenlerin mezun oldukları fakülte (eğitim fakültesi/fen edebiyat fakültesi) ve mesleki deneyimleri (1-5 yıl/6-10 yıl/10 yıldan fazla) değişkenleri ile 6 farklı durum belirlendikten sonra bu durumların her birine uyan 6 öğretmen belirlenmiştir.

\section{Veri toplama araçları}

Yapılandırmacı yaklaşımı benimseyen öğretim programına uygun olarak Geocebir yazılımı yardımıyla hazırlanan etkinliklerin öğrencilerin geometri derslerindeki performanslarına etkisi derinlemesine incelenmiş ve Geocebir etkinlikleri, doğru denklemleri performans testi (DDPT) ve yarı yapılandırılmış görüşme tekniği veri toplama-araçları olarak kullanılmıştır.

Çalışma kapsamında analitik düzlemde doğru denklemleri konusuna yönelik üç etkinlik hazırlanmıştır. Etkinlikler hazırlanırken etkinliğin amacı, sınıf yönetimi, etkinliğin birden fazla 
başlangıç noktasına sahip olması, kullanılacak araçlar, öğretmen ve öğrenci rolleri, öğrencilerin ön bilgileri, öğrenci zorluk ve yanılgıları, ölçme değerlendirme göz önünde bulundurulmuştur (MEB, 2011a; Özmantar ve Bingölbali, 2009). Uzman görüşü yardımıyla hazırlanan etkinliklerden birincisi doğrunun denklemi alt konusu ile ilgilidir ve araştırmacılar tarafından oluşturulmuştur. Etkinlikle gerçekleştirilmeye çalışılan amaç öğrencilere yapılandırmacı yaklaşımla, doğrunun geçtiği nokta ve paralel olduğu vektör verilerek Geocebir yazılımı yardımıyla doğrunun vektörel, parametrik ve kapalı denklemlerini oluşturmalarını sağlamaktır.

İkinci etkinlik eğim alt konusuna yöneliktir. Matematik öğretimi ile ilgili bir kitapta (Altun, 2009) yer alan etkinliğin çalışma grubundaki öğrencilerin özelliklerine göre Geocebir yazılımı ile tekrar düzenlenmesiyle hazırlanmıştır. Şekil 2'de yer alan bu etkinlik, çalışma grubundaki öğrencilerin dikkatini çekmek ve etkinlikteki grafiklerin çiziminde ve eğimlerin hesaplanmasında bilgisayar teknolojisini kullanmak için yeniden oluşturulmuştur.

Üçüncü etkinlik ise, doğruların birbirine göre konumları alt konusu ile ilgilidir ve araştırmacılar tarafından oluşturulmuştur. Bu etkinlikte öğrencilerden, Geocebir yazılımında yer alan "iki nesne arasındaki ilişki” aracı ile doğruların birbirleri ile olan durumlarını belirleyerek doğruların birbirine göre durumları ile eğimleri arasındaki ilişkiyi keşfetmeleri beklenmektedir.

\section{ETKINLİK-2 (Ĕ⿱im)}

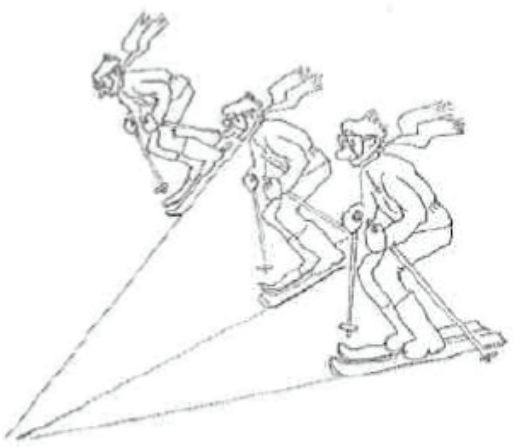

- Şekilde Davraz Kayak Merkezinde yer alan üç farklı pistte kayak yapan sporcular yer almaktadır. Sizce hangi sporcu daha hizlı kayar? Nedeni ile birlikte cevaplayıniz.

- Geogebra yaz1lımında $y=x, y=2 x$ ve $y=3 x$ doğrularının grafiklerini çiziniz. Bu doğruları resimdeki kayak pistleri olarak düşünecek olursak en hizli kayan sporcunun pistinin denklemi hangisidir?

- Pistlerin (doğruların) denklemlerini göz önünde tutarak sizce pistlerin dikleşmesinin sebebi nedir?

- Geogebra yazılımında Eğim aracını kullanarak pistlerin eğimlerini he saplayiniz.

- Sizce Geogebra yazılımı pistlerin eğimlerini nasil hesaplamaktadır, arkadaşınızla tartı̧̧arak cevaplam aya çalışınız.

Şekil 2. Eğim konusundaki etkinlik 
Araştırmacılar tarafından hazırlanan etkinliklerle bir sınıf bilgisayar laboratuvarında, diğer sınıf ise öğretim programına göre hazırlanan etkinliklerle sınıf ortamında geometri dersi gerçekleştirilmiştir. Geocebir yazılımıyla hazırlanan etkinliklerin, öğrencilerin analitik düzlemde doğru denklemleri konusuna yönelik performanslarına etkisini araştırmak amacıyla hazırlanan DDPT, eylem araştırmasını yürüten araştırmacı tarafından üç öğretim üyesi ve üç matematik öğretmeninin görüşleri alınarak oluşturulmuştur. Sorular, ders kitaplarındaki (MEB, 2011c), akademik çalışmalar (Aydoğan, 2007; Korucu, 2009; Budak, 2010; Demir, 2010) kapsamında hazırlanan başarı testlerindeki ve araştırmacılar tarafından oluşturulan sorulardan seçilmiştir. Hazırlanan testler, deneme çalışması yapılmak üzere 30 lise 9.sınıf öğrencisine uygulanmıştır. Deneme çalışması ve sonrasında alınan uzman görüşü sonucunda üç soru, öğrencilerin büyük çoğunluğu tarafından doğru cevaplanmadığından araştırma sorusuna katkı sağlamayacağı için testten çıarılmıştır.

Öğretmenlerin hazırlanan etkinliklerin öğrencilere ve öğretim programına uygunluğu, öğrencilerin konuların öğrenmelerinde faydalı olup olamayacağı hakkında görüşlerinin ortaya çıkarılması için öğretmenler ile yarı yapılandırılmış görüşmeler yapılmıştır. Görüşme formu, görüşme formunun hazırlanmasında dikkat edilmesi gereken ilkeler (Yıldırım ve Şimşek, 2008, s. 128) göz önünde bulundurularak, iki öğretim üyesinin yardımıyla hazırlanmıştır. Görüşme formunu test etmek için iki öğretmen ile deneme çalışması yapılmıştır.

\section{Verilerin çözümlenmesi}

Nitel paradigmaya sahip, nicel ve nitel veri sağlayan tekniklerin kullanıldığı bu araştırma sürecinde hangi istatiksel analizlerin ve süreçlerin kullanıldığı bu kısımda açıklanmıştır. Bilgisayar ve klasik sınıf ortamında öğrenim gören öğrencilere, doğru denklemleri konusu öğretim süreci bitiminden bir hafta sonra DDPT uygulanmıştır. Performans testi için hazırlanan cevap anahtarlarına göre öğrencilerin sorulara verdikleri cevaplar değerlendirilmiştir. Performans testinin analizinde iki basamaklı bir değerlendirme sistemi takip edilmiştir. Birinci basamakta, öğrencilerin cevapları doğru, kısmi doğru, yanlış ve boş olarak sınıflandırılmış ve puanlandırılmıştır. Doğru cevaplar 2 puan, kısmi doğru cevaplar 1 puan olarak değerlendirilmiş, yanlış ve boş cevaplara puan verilmemiştir. İkinci basamakta, içerik analiz yöntemi ile öğrenci çözüm süreçleri incelenmiş, soruların çözümünde tercih ettikleri yollar belirlenmiştir.

Öğretmenler ile yapılan yarı-yapılandırılmış görüşmelerin değerlendirilmesinde betimsel analiz yöntemi kullanılmıştır. Görüşme soruları, konunun öğretimi ve öğrencilerin öğrenmeleri açısından Geocebir yazılımının incelenmesi, yazılımın özellikleri ve yazılım hakkındaki olumlu olumsuz düşüncelerini ortaya çıkarmaya yönelik olduğundan görüşme verileri bu bağlamda sinıflandırılmıştır. Öğretmenlerin görüşlerini açık bir şekilde yansıtmak amacıyla doğrudan alıntılara yer verilmiştir.

\section{Bulgular}

$\mathrm{Bu}$ bölümde araştırma soruları doğrultusunda elde edilen nitel ve nicel veriler üzerinde 
yapılan analiz sonuçları açıklanmıştır. Öncelikle DDPT verileri puanlandırılarak nicel veri analiz tekniklerinin kullanımına uygun hale getirilmiştir. Nitel veriler ise öğretmenler ile yapılan yarıyapılandırılmış görüşmeler sonucunda elde edilmiştir. Öğretim sürecinde bilgisayar destekli öğrenim gören öğrenciler bilgisayar (B) sınıfı, öğretim programındaki etkinlikler ile öğrenim gören öğrenciler ise geleneksel $(G)$ sınıf ile ifade edilecektir.

\section{Öğrencilerin konuya yönelik performanslarının sonucu}

Analitik düzlemde doğru denklemleri konusuna yönelik Geocebir yazılımı yardımıyla hazırlanan etkinliklerle öğrenim gören öğrencilerin performansları ile öğretim programındaki etkinliklerle öğrenim gören öğrencilerin performanslarını incelemek için konunun öğretimi sonrasında iki sınıfa da DDPT uygulanmıştır. 16 tane klasik yazılı sorusundan oluşan testin iki sınıftaki öğrenciler tarafından cevaplanma yüzdeleri ve ortalama puanları Şekil 3'de verilmiştir.

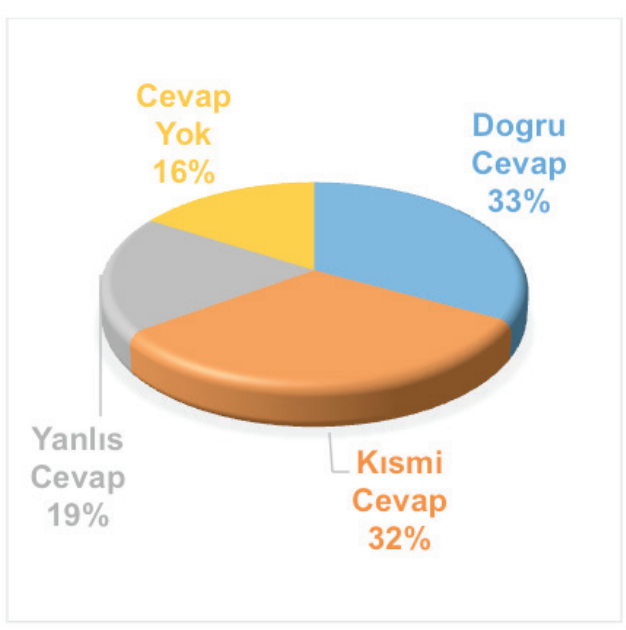

B Sınıfının Puan Ortalaması: 15,47

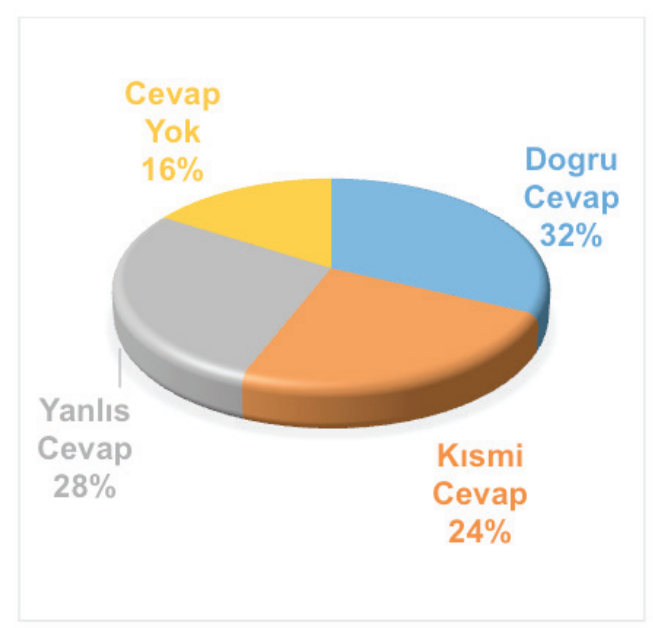

G Sınıfının Puan Ortalaması: 14

Şekil 3. DDPT’nin cevaplanma yüzdeleri ve ortalama puanları

B sınıfı öğrencileri ile G sınıfı öğrencilerinin DDPT’deki soruları doğru cevaplama yüzdeleri (\%33-\%32) birbirine çok yakındır. Testlerdeki sorulara kısmi doğru cevap verme yüzdeleri incelendiğinde B sınıfı öğrencilerinin oranları (\%32) G sınıfı öğrencilerine göre (\%24) daha yüksek olduğu görülmektedir. En yüksek 32 puan alınabilen B sınıfı öğrencilerinin ortalama puanları 15,47; G sınıfı öğrencilerinin ise 14'tür.

DDPT'de yer alan her soru analitik düzlemde doğru denklemleri konusu ile ilgili bir kavram ile ilgilidir. Tablo 1'de testte yer alan her sorunun öğrenciler tarafından cevaplanma yüzdeleri ve hangi kavram ile ilgili olduğu verilmiştir. Doğrunun vektörel, parametrik ve kapalı denklemleri kavramına yönelik 1., 2. ve 3. soruları B sınıfı öğrencileri \%31 doğru yanıt verirken G sınıfı öğrencileri \%22 doğru cevap vermişlerdir. Bu sorulara kısmi doğru cevap veren öğrencilerin oranları ise B sınıfında \% 41 , G sınıfında ise \%28'dir. 
Tablo I

DDPT'de Yer Alan Her Sorunun Hangi Kavrama Yönelik Olduğu ve Soruların Cevaplanma Yüzdeleri

\begin{tabular}{|c|c|c|c|c|c|c|c|c|c|}
\hline \multirow[t]{2}{*}{$\begin{array}{l}\text { Soru } \\
\text { No }\end{array}$} & \multirow[t]{2}{*}{ Kavram } & \multicolumn{2}{|c|}{$\begin{array}{c}\text { Doğru } \\
\text { Cevap }(\%)\end{array}$} & \multicolumn{2}{|c|}{$\begin{array}{c}\text { Kısmi } \\
\text { Cevap (\%) }\end{array}$} & \multicolumn{2}{|c|}{$\begin{array}{c}\text { Yanlış } \\
\text { Cevap } \\
(\%)\end{array}$} & \multicolumn{2}{|c|}{$\begin{array}{l}\text { Cevap Yok } \\
(\%)\end{array}$} \\
\hline & & B & G & B & $\mathbf{G}$ & B & $\mathbf{G}$ & B & G \\
\hline $1-a$ & \multirow{7}{*}{$\begin{array}{l}\text { Doğrunun Vektörel, Parametrik ve } \\
\text { Kapalı Denklemi }\end{array}$} & 58 & 29 & 16 & 29 & 26 & 36 & 0 & 6 \\
\hline $1-b$ & & 53 & 18 & 16 & 24 & 21 & 58 & 10 & 0 \\
\hline $1-\mathrm{c}$ & & 21 & 12 & 47 & 35 & 21 & 53 & 11 & 0 \\
\hline $2-a$ & & 16 & 35 & 62 & 24 & 11 & 35 & 11 & 6 \\
\hline $2-b$ & & 21 & 35 & 53 & 24 & 21 & 29 & 5 & 12 \\
\hline $3-a$ & & 37 & 12 & 37 & 35 & 16 & 41 & 10 & 12 \\
\hline \multirow[t]{2}{*}{ 3-b } & & 11 & 12 & 58 & 29 & 21 & 35 & 10 & 24 \\
\hline & Toplam & 31 & 22 & 41 & 28 & 20 & 41 & 8 & 9 \\
\hline 4 & Doğrunun Eğimi & 26 & 76 & 42 & 12 & 32 & 0 & 0 & 12 \\
\hline $5-a$ & Doğrunun Eğimi & 16 & 23 & 37 & 53 & 10 & 12 & 37 & 12 \\
\hline $5-b$ & Eğimin Yorumu & 63 & 29 & 5 & 0 & 21 & 59 & 11 & 12 \\
\hline $6-a$ & Doğrunun Denklemi ve Grafiği & 53 & 6 & 32 & 58 & 5 & 18 & 10 & 18 \\
\hline $6-\mathrm{b}$ & Doğrunun Eğimi & 26 & 47 & 0 & 6 & 42 & 6 & 32 & 41 \\
\hline $7-\mathrm{a}$ & Doğrunun Denklemi & 5 & 29 & 53 & 35 & 10 & 12 & 32 & 24 \\
\hline $7-b$ & Doğrunun Eğimi & 26 & 58 & 37 & 18 & 16 & 18 & 21 & 6 \\
\hline $7-c$ & Doğrunun Birbirine Göre Durumları & 58 & 59 & 0 & 6 & 16 & 12 & 26 & 23 \\
\hline \multirow[t]{2}{*}{8} & Doğrunun Birbirine Göre Durumları & 32 & 23 & 10 & 0 & 21 & 18 & 37 & 59 \\
\hline & TOPLAM & 33 & 32 & 32 & 24 & 19 & 28 & 16 & 16 \\
\hline
\end{tabular}

DDPT de doğrunun eğimi ile ilgili dört soru (4, 5-a, 6-b, 7-b), eğimin yorumu ile ilgili de bir soru (5-b) vardır. Doğrunun eğimi ile ilgili sorulara $G$ sınıfı öğrencileri B sınıfı öğrencilerine göre daha fazla doğru cevap vermişlerdir (\%26-\%76, \%16-\%23; \%26-\%47; \%26-\%58). İki sinıf arasındaki farkın en fazla olduğu 4. soruda (\%26-\%72) B sınıfındaki öğrencilerin soruları kısmi olarak cevaplama yüzdesi \%42 iken, G sınıfındaki öğrencilerin \%12'dir. Eğimin yorumu ile ilgili 5-b sorusunu ise B sınıfı öğrencileri G sınıfı öğrencilerine daha yüksek oranda doğru olarak cevaplamışlardır (\%63-\%29). Doğrunun denklemi ve grafiği ile ilgili 6-a sorusunu B sınıfındaki öğrenciler \%53 oranında doğru cevaplarken \%32 oranında kısmi olarak cevap vermişlerdir. G sınıfı öğrencilerinin ise sadece \%6’sı soruyu doğru olarak cevaplarken \%58’i soruya kısmi cevap vermiştir. Doğrunun birbirine göre durumları kavramına yönelik 7-c ve 8. soruların cevaplanma yüzdeleri incelendiğinde ise 7-c sorusunun doğru cevaplanma yüzdeleri daha yüksek iken (\%58-\%59), 8.soruda doğru cevap yüzdeleri azalmıştır (\%32-\%23). Ancak 8. soruda B sınıfındaki öğrencilerin doğru cevap yüzdesi (\%32-\%23) ve kısmi cevap yüzdesi (\%10-\%0) G sınıfına göre daha fazladır.

DDPT'de yer alan Şekil 4'deki sorular analitik düzlemde doğruların vektörel, parametrik ve kapalı denklemleri ile bu denklemler arasındaki geçişler ile ilgilidir ve bunlar iki gruba da anlatılırken doğrunun genel denkleminden yararlanılmıştır. B grubundaki öğrenciler genel denklemin nasıl oluştuğunu Geocebir yazılımı ile keşfederken, G sınıfı öğrencilerine ise genel 
denklemin nasıl oluştuğu öğretmen tarafından anlatılmıştır. Genel denklem oluşturulduktan sonra iki gruba da vektörel, parametrik ve kapalı denklemlerin genel denklemden yararlanarak oluşturulması gösterilmiştir. Şekil 4'deki soru iki farklı yoldan cevaplanabilir. Birinci yol; doğrunun genel denklemi oluşturularak buradan vektörel-parametrik ve kapalı denklemlerinin oluşturulmasıdır. İkinci yol ise doğrunun vektörel-parametrik ve kapalı denklemlerinin kural üzerinden yazılmasıdır.

1) $\vec{u}=(3,2)$ Vektörüne paralel ve $\mathrm{A}(-2,0)$ noktasından geçen doğrunun vektörel, parametrik ve kapalı denklemlerini olușturunuz.

2) Vektörel denklemi $(x-2, y-1)=k \cdot(-3,5)$ olan doğrunun parametrik ve kapalı denklemlerini oluşturunuz.

3) Parametrik denklemi

$$
\begin{aligned}
& x=-4+3 t \\
& y=2-t
\end{aligned}
$$

Olan doğrunun vektörel ve kapalı denklemlerini olușturunuz.

Şekil 4. Analitik düzlemde bir doğrunun parametrik-vektörel-kapalı denklemi ile ilgili sorular

Tablo 2'de doğrunun vektörel, parametrik ve kapalı denklemleri ile ilgili soruları B ve G sınıfı öğrencilerinin hangi yöntemle cevapladığı verilmiştir. İlgili sorulara doğru cevap verme yüzdeleri B sınıfındaki öğrencilerin daha fazladır (\%30-\%23). İki sınıftaki öğrenciler soruları daha çok doğrunun genel denklemini oluşturarak doğru cevaplasalar da (\%19-\%11; \%13-\%10) B sınıfı öğrencileri G sınıfı öğrencilerine göre daha çok bu yöntemi tercih etmişlerdir (\%19-\%13). $B$ ve $G$ sınıfındaki öğrencilerin bu sorulardan aldıkları puanların ortalaması incelendiğinde $B$ sınıfındaki öğrencilerin (ort. p.: 1,03) G sınıfındaki öğrencilerden (ort. p.: 0,72) daha başarılı oldukları görülmektedir. Ayrıca ortalama puan değerinin en yüksek 2 olduğu göz önüne alınırsa G grubu öğrencilerinin başarılarının \%50’nin altında olduğu söylenebilir.

\section{Tablo 2}

Doğrunun Vektörel-Parametrik ve Kapalı Denklemleri ile Ilgili Soruların B ve G Sınıfındaki Öğrenciler

\begin{tabular}{|c|c|c|c|c|c|c|c|c|c|c|}
\hline \multirow{2}{*}{ 莺 } & \multirow{2}{*}{$\mathrm{N}$} & \multicolumn{3}{|c|}{ Doğru Cevap (\%) } & \multicolumn{3}{|c|}{ Kısmi Cevap (\%) } & \multirow{2}{*}{$\begin{array}{c}\text { Yanlış Cevap } \\
(\%)\end{array}$} & \multirow{2}{*}{$\begin{array}{c}\text { Cevap Yok } \\
(\%)\end{array}$} & \multirow{2}{*}{$\begin{array}{l}\text { Ortalama } \\
\text { Puan }\end{array}$} \\
\hline & & 1.yol & 2.yol & Top. & 1.yol & 2.yol & Top. & & & \\
\hline $\mathrm{B}$ & 19 & 19 & 11 & 30 & 17 & 25 & 42 & 20 & 8 & 1,03 \\
\hline G & 17 & 13 & 10 & 23 & 14 & 14 & 28 & 41 & 8 & 0,72 \\
\hline
\end{tabular}
Tarafindan Cevaplanma Yüzdeleri 
Şekil 5'de doğrunun vektörel, parametrik ve kapalı denklemi ile ilgili soruyu birinci ve ikinci yoldan doğru ve kısmi olarak cevaplayan dört öğrencinin cevapları yer almaktadır. Birinci cevapta B sınıfındaki bir öğrenci, doğrunun denklemlerini genel denklemi yazarak (birinci yol) oluşturmuştur. İkinci cevapta yine B sınıfındaki bir öğrenci doğrunun denklemlerini vektörel, parametrik ve kapalı denklemin kurallarından (ikinci yol) yazmıştır. Üçüncü cevapta G sınıfındaki öğrenci birinci yolu kullanarak doğrunun denklemlerini oluşturmaya çalışmıstır. Vektörel ve parametrik denklemleri doğru bir şekilde cevaplayan öğrenci kapalı denklemi oluştururken hata yapmıştır. Bu nedenle öğrencinin çözümü kısmi cevap olarak değerlendirilmiştir. Dördüncü cevapta B sınıfındaki bir öğrencinin doğrunun denklemlerini ikinci yolu kullanarak cevaplamıştır. Vektörel ve parametrik denklemleri doğru bir şekilde yazan öğrenci üçüncü cevapta olduğu gibi kapalı denklemi yazarken hata yapmıştır. Bu öğrencinin çözümü de kısmi cevap olarak değerlendirilmiştir.

\begin{tabular}{|c|c|c|c|}
\hline $\begin{array}{c}1 \\
(d / 1)\end{array}$ & 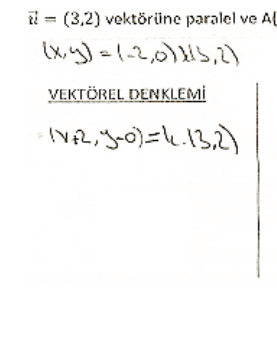 & $\begin{array}{l}\{-2,0) \text { noktasindan geçen doğrunur } \\
\begin{array}{l}\text { PARAMETRIK DENKLEMI } \\
\begin{array}{l}y=-2+3 h \\
y=0+2 l\end{array}\end{array}\end{array}$ & $\begin{array}{l}\text { KAPALI DENKLEMI } \\
\frac{v+2}{3} * \frac{y-0}{2} \\
2 \cdot(v+2)=3(1 y-0) \\
2 v+4=3 y+0 \\
2 x+4-2 y-0=0 \\
2 x-3 y+4=0\end{array}$ \\
\hline $\begin{array}{c}2 \\
(d / 2)\end{array}$ & $\begin{array}{l}u=(3,2) \text { vektörüne parale } \\
\text { VEKTöREL DENKLEMI } \\
(x+2, y-0) \neq k .(3,2)\end{array}$ & $\begin{array}{l}\text { el ve A(-2,0) noktasindan gesen dog̈r } \\
\qquad \begin{array}{l}\text { PARAMETRIK DENKLEMI } \\
\begin{array}{l}x=2+3 k \\
y=-0+2 k\end{array}\end{array}\end{array}$ & \begin{tabular}{|l}
$\frac{x+2}{3} \times \frac{y-0}{2}$ \\
$\begin{array}{l}2 x+4=3 y-0 \\
2 x-3 y+4=0\end{array}$
\end{tabular} \\
\hline $\begin{array}{c}3 \\
(k . c . / 1)\end{array}$ & $\begin{array}{l}\vec{u}=(3,2) \text { vektörüne paralel ve } n \\
\begin{array}{c}\text { VEKTö̈REL DENKLEMI } \\
A(-2,0) \\
\overrightarrow{3}(3,2) \\
(x, y)=(-2,0)+(3,2) \\
(x+2, y-0)=k \cdot(3,2\end{array}\end{array}$ & $\begin{array}{l}M(-2,0) \text { noktasindan gesen dog̈run } \\
\text { PARAMETRiK DENKLEMI } \\
A(-2,0) \\
\vec{U}(3,2) \\
(x, y)=(-2,0)+(3,2) \\
2)_{x=-2+3 k} \\
y=0+2 k\end{array}$ & $\begin{array}{l}\text { un: } \\
\qquad \begin{array}{l}A(-2,0) \\
\overrightarrow{\text { KAPALI DENKLEMI }} \\
\vec{t}(3,2) \\
(x, y)=(-2,0)+(3,2) \\
\frac{x-2}{3} \times \frac{y-0}{2}\end{array}\end{array}$ \\
\hline $\begin{array}{c}4 \\
\text { (k.c./2) }\end{array}$ & $\begin{array}{l}u \vec{u}=(3,2) \text { vektörüne paralel } \\
\text { VEKTöREL DENKLEMI } \\
(x+2, y-0)=k \cdot(3,2)\end{array}$ & $\begin{array}{l}\text { lel ve } A(-2,0) \text { noktasindan geçen do } \\
\qquad \begin{array}{l}\text { PARAMETRIK DENKIEM } \\
\begin{array}{l}x-2+3 \cdot k \\
y=0+2 \cdot k\end{array}\end{array}\end{array}$ & KAPALI DENKLEMI \\
\hline
\end{tabular}

Şekil 5. Doğrunun denklemleri ile ilgili soruya ait öğrenci cevapları 
DDPT'de yer alan Şekil 6'daki soru analitik düzlemde doğrunun eğiminin hesaplanması ile ilgilidir. Doğrunun eğimi konusunun öğretiminde iki grupta yer alan öğrencilere de doğrunun grafiğinden yararlanılarak eğimin bulunması ile ilgili etkinlik yapılmıştır. B sınıfındaki öğrencilere grafik üzerinde Geocebir yazılımının doğrunun eğimini nasıl hesapladığı sorularak, eğim kuralını kendilerinin oluşturması sağlanmıştır. G sınıfındaki öğrencilere ise öğretim programında yer alan etkinlik uygulanmıştır.

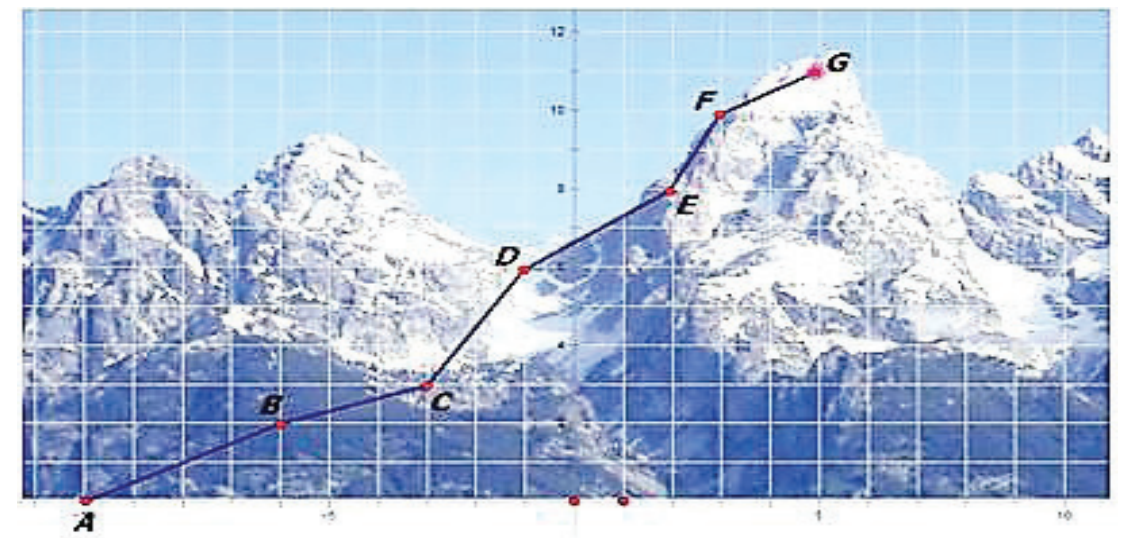

SSekildeki $A$ noktasmda yer alan bir dağcr dağm zirvesi olan $G$ noktasina tumanacaktir.

Dağcunn izleyeceği yollann $A B, B C, C D, D E, E F, F G$ eğimlerini hesaplaynz.

Şekil 6. Analitik düzlemde doğrunun eğiminin hesaplanması ile ilgili soru

Doğru eğimlerinin hesaplanmasının öğretimi sırasında eğimin iki farklı yoldan hesaplanabildiği ifade edilmiştir. Birinci yol, şekil üzerinden y eksenindeki değişim miktarının x eksenindeki değişim miktarına oranlanması; ikinci yol ise noktaların koordinatları belirlendikten sonra iki noktadan geçen doğrunun eğimi kuralından hesaplanmasıdır.

\section{Tablo 3}

Doğrunun Eğiminin Hesaplanması ile Illgili Sorunun B ve G Sınıfindaki Öğrenciler Tarafindan Cevaplanma Yüzdeleri

\begin{tabular}{|c|c|c|c|c|c|c|c|c|c|c|}
\hline \multirow{2}{*}{ 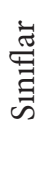 } & \multirow[t]{2}{*}{$\mathrm{N}$} & \multicolumn{3}{|c|}{ Doğru Cevap (\%) } & \multicolumn{3}{|c|}{ Kısmi Cevap (\%) } & \multirow{2}{*}{$\begin{array}{c}\text { Yanlış } \\
\text { Cevap } \\
(\%)\end{array}$} & \multirow{2}{*}{$\begin{array}{c}\text { Cevap } \\
\text { Yok } \\
(\%)\end{array}$} & \multirow{2}{*}{$\begin{array}{l}\text { Ortalama } \\
\text { Puan }\end{array}$} \\
\hline & & 1.yol & 2.yol & Top. & 1.yol & 2.yol & Top. & & & \\
\hline B & 19 & 0 & 16 & 16 & 5 & 32 & 37 & 10 & 37 & 0,68 \\
\hline G & 17 & 0 & 23 & 23 & 6 & 47 & 53 & 12 & 12 & 0,82 \\
\hline
\end{tabular}


Doğrunun eğiminin hesaplanması ile ilgili soruyu B ve G sınıfı öğrencilerinin hangi yöntemle cevapladığını veren Tablo 3’e göre ilgili sorulara doğru cevap verme yüzdeleri G sınıfındaki öğrencilerin daha fazladır (\%16-\%23). İki sınıftaki öğrencilerden hiç biri soruyu birinci yoldan doğru cevaplayamamıştır. Kısmi cevaplar incelendiğinde de G sınıfındaki öğrenciler B sınıfına göre soruya daha çok cevaplamışlardır (\%53-\%37) ve daha çok ikinci yolu tercih etmişlerdir (\%5\%32, \%6-\%47). Puanların ortalamasına bakıldığında ise G sınıfı öğrencileri B sınıfı öğrencilere göre daha başarılı olsa da $(0,82-0,68)$ iki sınıf öğrencilerinde başarıları \%50'nin altındadır.

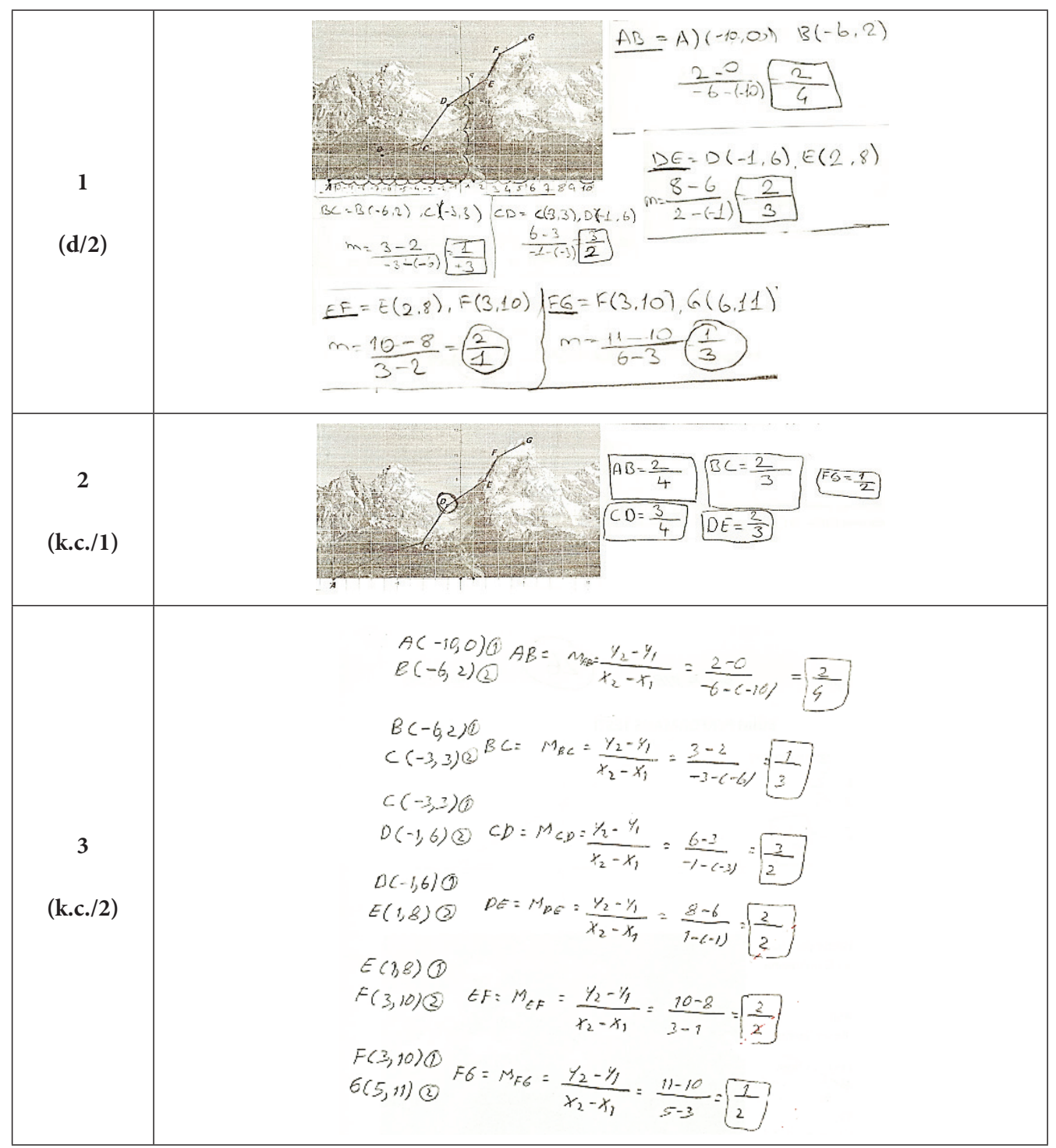

Şekil 7. Analitik düzlemde eğim hesabı ile ilgili soruya ait öğrenci cevapları 
Şekil 7’de doğrunun eğiminin hesaplanması ile ilgili sorulara ait üç öğrencinin cevapları yer almaktadır. Birinci cevap G sınıfındaki bir öğrenciye aittir. Soruda istenen doğru parçalarının eğimlerini iki noktadan geçen doğrunun eğimi kuralı (ikinci yol) ile cevaplayan öğrenci 6 doğru parçasının eğimini de doğru hesaplamıştır. İkinci cevapta şekil üzerinden (birinci yol) soruyu cevaplamaya çalışan öğrencinin çözümü yer almaktadır. ve doğru parçalarının eğimini doğru hesaplayan öğrencinin çözümü kısmi cevap olarak değerlendirilmiştir. Üçüncü cevapta soruyu eğim kuralından (ikinci yol) hesaplamaya çalışan öğrenci ve doğru parçalarının eğimlerini doğru hesaplamıştır. E noktasının koordinatını yanlış hesaplayan öğrenci diğer doğru parçalarının eğimlerinin hesabında hata yapmıştır. Bu nedenle öğrencinin cevabı kısmi cevap olarak değerlendirilmiştir.

Hazırlanan etkinliklerle gerçekleştirilen öğretim sadece DDPT sonuçları ile değerlendirilmemiştir. Bunun yanında, hazırlanan etkinlikler ve bilgisayar destekli matematik öğretimi hakkında belirlenen altı öğretmenin görüşleri ortaya çıkarılmıştır.

\section{Öğretmenlerin hazırlanan etkinlikler hakkındaki görüşleri}

Öğretmenler ile yapılan görüşmelerde hem Geocebir ile ilgili doğru denklemleri konusunun öğretimi açısından düşünceleri hem de hazırlanan etkinlikler hakkında görüşleri ortaya çıkarılmıştır.

Öğretmenlerin tamamı Geocebir yazılımının doğru denklemleri konusunun öğretimi açısından çok faydalı olacağını belirtmiş̧ir. Yalnızca Ö1, etkinlik-1 de (doğrunun denklemi), doğrunun parametrik, vektörel ve kapalı denklemlerinin öğretiminde giriş bölümü dışında kullanmanın gereksiz olduğunu belirtmiştir. Öğretmenlerin bazıları Geocebir’ in hesap yapabilme özelliğini vurgulamıştır. Ö6 ise, doğruların grafiklerinin pratik olarak çizilebilmesi özelliğinin çok yararlı olduğunu ifade etmiştir.

Ö6: "Yazılımın grafiği kendisinin çizmesi çok güzel. Öğrenci nasıl çizilebileceğini biliyor ancak detayla uğraşmıyor, öğrencinin dikkati dă̆ılmıyor."

Ö2, Geocebir’in bu konu için çok uygun olduğunu vurgulamış ve dikkatini çeken özelliği belirtmiştir.

Ö2: "Geocebir yazılımı sanki bu konular için hazırlanmış bir yazılım gibi. Öğrencilere faydalı olacağın düşünüyorum. Çizilen doğruların birbirleri arasındaki ilişkiyi gösteren araç çok güzel..."

Öğretmenlerin yarısı Geocebir'in eğim hesabında çok kullanışlı olduğunu belirtmiştir. Ö1, bağıntısının grafiksel olarak Geocebir yazılımda gösteriminin çok faydalı olduğunu ifade etmiştir. 
Analitik düzlemde doğru denklemleri bölümünde üç etkinlik vardır. Bunlardan birincisi doğrunun vektörel, parametrik ve kapalı denklemi kavramlarıyla, ikincisi doğrunun eğimiyle, üçüncüsü ise doğrunun birbirine göre durumlarılya ilgilidir. Öğretmenlerin çoğu hazırlanan üç etkinliğinde öğrencilerin bu konuyu öğrenmelerinde faydalı olacağını belirtmiştir. Ö3, etkinliklerin faydalı olmasını, etkinliklerin keşfederek öğrenme yöntemine uygun olarak hazırlanması ile açıklamıştır.

Ö3: "Doğru denklemleri konusunda parametrik, kapalı denklemi doğrudan verebilirdin ancak etkinlikler tamamen öğrencilerin adım adım kendilerinin keş̧fetmesini sağlayacak şekilde tasarlanmış. Bu nedenle etkinlikler gerçekten faydalı. Etkinlikler içerisinde doğrudan bilgi yok, ufak bilgilerle sonuca ulaşmaya çalş̧llan etkinlikler var. Bu nedenle gerçekten etkili olmuş."

Ö3 gibi Ö2 de doğrunun denklemleri etkinliğini genelleyerek bu soruyu cevaplamıştır. Ö2, doğrunun vektörel, parametrik ve kapalı denklemlerinin birbiriyle bağlantılı olduğunu, öğrencilerin keşfetmesinin konunun öğrenilmesi açısından çok önemli olduğunu belirtmiştir.

Öğretmenlerin yarısından fazlası etkinliklerde günlük hayattan örneklerin yer almasını konunun öğretimi açısından etkili olduğunu ifade etmiştir. Ö6’nın cevabı şu şekildedir:

Ö6: "Bu etkinliklerle dersi işlemek daha kalıı olur. Örneklerin güncel hayatla örtüşmesi güzel..."

Ö5 ise etkinliklerde ölçme değerlendirme sorularına vurgu yapıp, etkinliklerin faydalı olacağını ifade etmiştir.

Ö5: "Etkinliklerin faydalı olacağın düşünüyorum, gayet güzel hazırlanmış. Ayrıca bazı ölçme değerlendirme sorularını öğrencinin Geocebir yazılımı ile yapıp kontrol etmesi de çok faydah olmuş."

Öğretmenlerden bazıları doğrunun birbirine göre durumları kavramına yönelik etkinliğin (etkinlik-3) dikkat çekici olduğunu belirtmiştir. Ö3, etkinlikteki öğrenci merkezlilik anlayışına vurgu yapmıştır.

Ö3: "Doğruların birbirine göre durumlarında, etkinlik-3 de doğruların Geocebir ile grafiklerini çizip, yine Geocebir ile birbirine göre durumlarınn test edilmesi süper olmuş bence. Öğrencilere ilk önce doğrularm paralel olduğunu düşünmeden yazllımla buldurtuyorsun. Daha sonra iki doğru birbirine paralel ise denklemleri arasında nasil bir ilişki vardır diye özellikleri keş̧ettirmen çok güzeldi." 
Öğretmenler, doğrudenklemlerikonusundahazırlanan dersplanındaveuygulamasürecindeki eksiklikleri ve bu eksikliklerin giderilmesi için önerilerini belirtmişlerdir. Öğretmenlerin yarısı eğim kavramına yönelik etkinlik-2 hakkında düşüncelerini paylaşmışlardır. Ö4, eğim hesabında tanjantın daha fazla vurgulanması gerektiğini belirtmiş, Ö2 ise tanjant kavramı verildikten sonra tanjant ile ilgili örnek sayısının arttırılması gerektiğini vurgulamıştır. Ö3 ise doğrunun birbirine göre durumlarının öğrencilere keşfettirilmesi için bir öneride bulunmuştur.

Ö3: "Birbirine paralel iki doğru oluşturulup bir doğru hareket ettirildiğinde diğer doğruda paralel kalacak şekilde hareket ederken, değișmeyenler ne gibi soru sorularak paralel doğrularm özellikleri keşfettirilebilir."

Etkinliklerin öğretim programına uygunluğu açısından öğretmen görüşleri incelendiğinde öğretmenlerin yarısından fazlası öğretim programına uygun olduğunu düşünmektedir. Ö4, ölçme değerlendirme sorularının arttırılması gerektiğini belirtmiştir.

Ö4: "Uygun ancak bu etkinlikler ile öğrenci üniversite sinavindaki soruları çözemeye bilir bu nedenle ölçme değerlendirme soruları arttırılmalı"

Öğretmenlerin, hazırlanan etkinlikler hakkındaki görüşlerini bir bakışta görebilmek amacıyla Şekil 8 hazırlanmıştır.
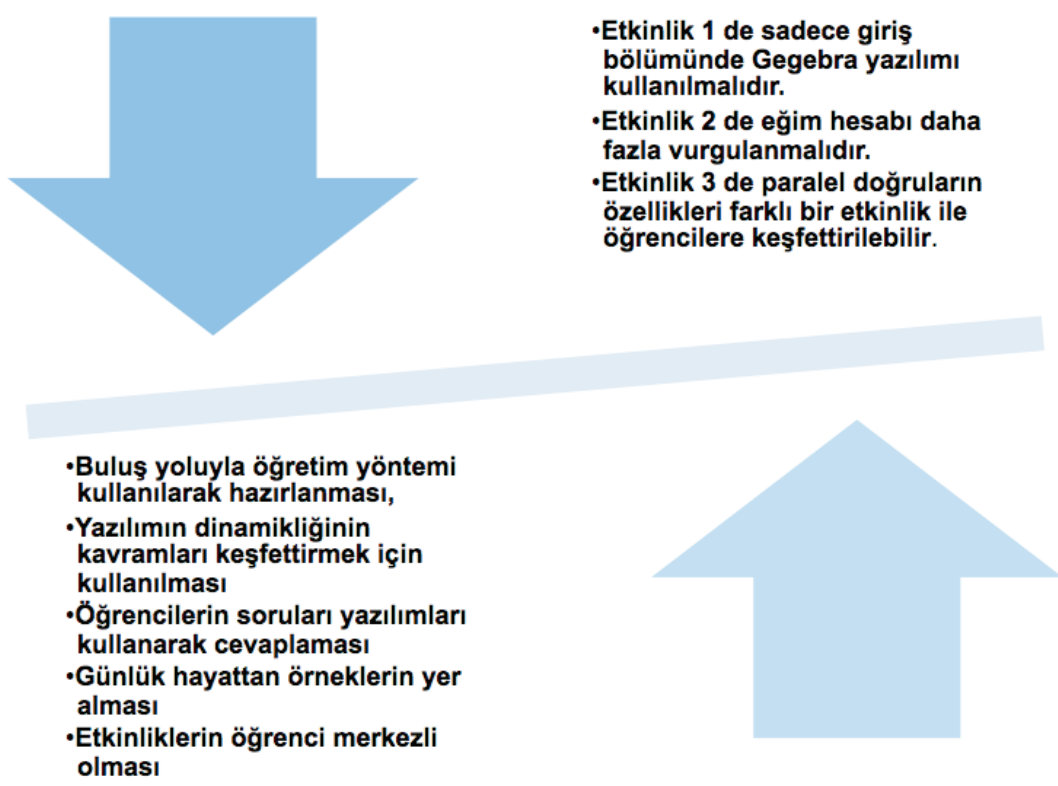

Şekil 8. Öğretmenlerin hazırlanan etkinlikler hakkındaki görüşleri 


\section{Tartışma}

Vektörel, parametrik ve kapalı denklem kavramlarına yönelik sorularda B sınıfı öğrencileri daha başarılı olmuştur. Buna gerekçe olarak doğru denklemleri konusuna yönelik yapılan çalışmalarda, öğrencilerin konuyu öğrenmelerinde ve kavram yanılgılarını gidermede bilgisayar destekli yazılımların kullanılmasının etkili olmasının kabulü gösterilebilir (Kutluca ve Birgin, 2007). Doğru denklemleri kavramına yönelik hazırlanan etkinlikler, öğrencilerin buluş yoluyla öğrenmelerini sağladığı için öğretmenler tarafından faydalı bulunmuştur. Ö2'nin “... doğrunun vektörel, parametrik ve kapalı denklemlerinin birbiriyle bağlantılı olduğunu öğrencilerin keşfetmesi konunun öğrenilmesi açısından çok önemli...” ifadeleri bunu destekler niteliktedir.

G sınıfı öğrencileri doğrunun eğiminin hesaplanması ile ilgili sorularda, B sınıfı öğrencileri ise eğimin yorumlanması ile ilgili sorularda daha başarılı olmuşlardır. Dinamik geometri yazılımlarının kazandırdığı becerilerden biri olarak kabul edilen görselleme becerisi (Kağızmanlı ve Tatar, 2012) sadece şekil oluşturmada değil süreçte gerçekleştirilen içselleştirme sayesinde grafik yorumlama sorularında öğrencilerin daha iyi performans sergilemelerine neden olmuş olabilir ki böylelikle sonuç değil süreç odaklı bir kavramsal anlamaya sebep olduğu da ifade edilebilir. Geocebir yazılımı ile hazırlanan etkinlik-2 de günlük hayattan bir örneğin yer alması öğrencilerin eğim kavramını yorumlamalarını olumlu yönde etkilediği düşünülebilir. Bunun sebeplerinden birisi olarak, öğrencilerin alışılagelmiş cebirsel ağırlıklı geleneksel öğretim yaklaşımdan farklı olarak teknoloji ve yapılandırmacı yaklaşımın da desteklediği günlük hayat problemleri ile muhatap olması gösterilebilir. Ayrıca öğretmenler de etkinlikte günlük hayattan örneklerin yer almasını konunun öğretimini olumlu yönde etkilediğini ifade etmişlerdir. İki sinıfta yer alan öğrenciler de, bir doğrunun eğimini hesaplarken doğrunun grafiğini değil de iki noktadan geçen eğim kuralını kullanmışlardır. Ö4, eğim hesabında “Tanjant” kavramının daha fazla vurgulanması gerektiğini önermiştir, bu öğretim programı reform hareketi öncesi paradigma ile sonrasının karşılaştığı bir durum olarak kabul edilebilir. Tanjant, trigonometrik fonksiyonlarda ve eğim hesaplamada en çok kullanılan kurallardandır ayrıca dinamik bir ortamın olmadığı durumlarda grafikteki farklı iki noktanın oluşturduğu koordinat düzlemindeki dik üçgeninde bu kuralın kullanılmasına katkıda bulunduğu söylenebilir.

Geocebir, dinamik geometri yazılımı olarak adlandırılsa da (Karakırık, 2011, s. 72) matematik öğretiminde matematiksel kavramların keşfedilmesinde de kullanılmaktadır (Baydaş, 2010; Karakırık, 2011). Geocebir yazılımı hem cebir hem de geometriyi beraber dinamik olarak ele aldığı için dinamik matematik yazılımı olarak da adlandırılmaktadır (Kabaca, 2006; Taş 2010; Baydaş 2010). Öğretim süreci öncesinde öğretmenler ile yapılan görüşmelerde dinamik yazılımların daha çok geometri eğitiminde kullanılması gerektiği belirtilmiştir. Bu düşüncelerinin sebepleri matematik yazılımları hakkında fazla fikir sahibi olmamaları ya da kullanıcısı durumunda olmamalarından kaynaklı bilgisayarın sadece şekil çizmek amacıyla kullanılacağını düşünmelerinden olabilir. Bununla birlikte hazırlanan etkinlikleri izledikten sonra görüşlerinin değiştiği ve hem cebir hem de geometri de yazılımların kullanabileceğini belirtmişlerdir.

Bilgisayar destekli öğretim hakkında daha önce bir eğitim almayan öğretmenler, etkinlikler 
tanıtılmadan önce BDÖ’nün en çok soyut kavramları görselleştirmesi bakımından yararlı olacağını belirtmişlerdir. $\mathrm{Bu}$ yaklaşımları, görselleştirmeyi matematiğin soyut yapısından kaynaklanan öğrenme güçlüklerini gidermek amacıyla soyut kavramların olabildiğince somutlaştırmasını sağlayan bir araç olarak düşünmelerinden kaynaklanabilir (Iş̧ı ve Konyalığlu, 2005). Öğretmenlerin bilgisayar destekli öğretimin görselleştirme özelliğine, çevrelerinden edindikleri bilgiler, internet ortamında sunulan manipülatifler ve öğretmenler arasında dolaşan Java uygulamaları sayesinde eğitim almadan vurgu yaptı̆̆ı da ayrıca düşünülebilir.

Bilgisayar destekli öğretimin yararları olduğu gibi sınırlılıklarından da söz edilebilir. Bazı öğretmenler bilgisayar destekli öğretimin özellikle derse giriş bölümünde yapılması gereken hazırlıklar açısında zaman alıcı olduğunu belirtmişlerdir. Özellikle öğrencilerin bilgisayar destekli öğretime alışma sürecinde bu olumsuzluk yaşanabilmektedir. Ancak uzun zamanlı düşünüldüğünde bilgisayar destekli eğitiminin zaman kazancı sağlayacağı düşünülebilir. $\mathrm{Bu}$ düşünceleri paylaşan öğretmenler, bilgisayar ortamında dinamik matematik ve geometri yazılımları ile öğretim yapmışlardır. Daha önce bilgisayar destekli matematik ve geometri öğretimi hakkında eğitim almamış ve deneyim sahibi olmayan öğretmenler, bilgisayar destekli öğretim hakkında bir olumsuzluk belirtmemişlerdir. Buradan, BDÖ ile ilgili sorunların ve çözüm yollarının deneyimle ortaya çıktığı düşünülebilir. O halde çözüm önerilerinin de bu süreç ile ortaya çıkması beklenebilir. Bunun da dinamik geometri yazılımlarını kullanmayı öğrenen öğretmenlerin yazılımları, avantajları ve sınırlılıkları açısından değerlendirip uygun konularda uygun yazılımları kullanmalarına sebep olacağı söylenebilir (Karaaslan, 2013).

Öğretim programlarında yer alan etkinliklerde dinamik geometri yazılımlarının kullanılabileceği ifade edilmekte (MEB, 2011b), ancak bu yazılımları nasıl kullanacağı belirtilmemektedir. Hazırlanan etkinlik örneklerini izledikten sonra hem daha önce yazılımlar hakkında eğitim almamış öğretmenler, hem de daha önce derslerinde bu yazılımları kullanan öğretmenlerin bilgisayar destekli matematik öğretimine karşı düşünceleri olumlu yönde gelişmiştir. Daha önce eğitim almamış öğretmenler özellikle öğrencinin derste aktif olmasından dolayı yazılımı derslerinde kullanacaklarını belirtmişlerdir. Dinamik geometri yazılımları ile hazırlanan etkinliklerin, öğrenciye öğrenilen içerikle ilgili performansını gösterebilme imkânı vermesinin, öğrencilerin sürekli derse katılmasını sağlaması açısından önemi vurgulanabilir.

Geocebir yazılımını matematik derslerinde kullanmaya çalışan ve etkinlikleri izlemeden önce matematik ve geometri derslerinde bilgisayar kullanmanın zaman alıcı olduğunu ifade eden öğretmenlerin görüşlerinin olumlu yönde değiştiği gözlenmiştir. Ö2'nin 'Etkinlikleri izledikten sonra şunu söyleyebilirim ki, bilgisayar destekli öğretimin hem öğrenci hem de öğretmen açısından uygulanabileceğini ve düzenli yapılan çalışmalarla öğretim ve öğrenimde çok verimli olacağını düşünüyorum" ifadeleri bunu destekler niteliktedir.

Dinamik geometri yazılımlarını daha önce kullanan diğer iki öğretmen de etkinliklerin kendileri için hem konu hakkında fikir sahibi olmak, hem de konunun öğretimi açısından kullanabilecekleri materyaller olması sebebiyle çok faydalı olacağını belirtmişlerdir. $\mathrm{Bu}$ ifadelerden, hazırlanan etkinliklerin güzellik ve ilgi çekiciliğinden ziyade uygulanabilirliğinin 
yüksek olduğunu ve öğretmenlerin bilgisayar destekli öğretim hakkındaki düşüncelerini olumlu yönde etkilediği söylenebilir.

Öğretmenlerin her ders için etkinlik hazırlamaları mümkün değildir. Öğretmenler ve akademisyenler tarafından geliştirilen etkinliklerin bir arada toplandığı ve paylaşıldığı bir ortam oluşturulması gerekir (Kutluca ve Birgin, 2007). Öğretmenlerden Ö6, bu ortamı MEB'in FATİH projesi ile oluşturduğu EBA gibi olması gerektiğini düşünmektedir. Böyle bir ortam sağlandığında, öğretmen hangi konuyu anlatacaksa o konu ile ilgili etkinlikleri inceleyip kendisine göre düzenleyebilir.

Öğretim sürecinde öğrencilerden gelen dönütler ve araştırmacının gözlemleri ile öğretmenlerin görüşleri doğrultusunda hazırlanan etkinlikler geliştirilebilir. Doğru denklemleri kavramlarının etkinlik-1 ile öğretiminin hem öğrenci hem de öğretmen görüşleri doğrultusunda çok yararlı olduğu ortaya konulmuştur. Öğrencilerin birbirleri ile ilişkilendirmekte zorluk çektiği, doğrunun vektörel, parametrik ve kapalı denklemlerinin öğretiminde bu etkinliğin kullanılması öğrencilerin konuyu anlamalarına yardımcı olabilir. Etkinlik-2 de günlük hayattan bir problemin yer alması öğrencilerin ilgisini ve başarısını olumlu yönde etkilemiş, öğretmenler tarafından da konunun öğretimi açısından önemi vurgulanmıştır. Bu nedenle etkinlikler geliştirirken mümkün olduğunca günlük hayat problemlerine yani gerçek senaryolara yer verilebilir. Etkinlik-2, eğimin "tanjant" yardımı ile hesaplanması açısından geliştirilirse, öğrenciler doğrunun eğimini hesaplarken doğrunun grafiğini de etkili bir şekilde kullanarak doğru sonuca ulaşabilir. Etkinlik-3'te doğruların birbirilerine göre durumlarının belirlenmesinde Geocebir yazılımının kullanılması, öğrencilerin doğruların birbirine dik ve paralel olma özelliklerini keşfetmesini sağlamaktadır. Ancak paralel ve dik doğruların özellikleri Geocebir yazılımının dinamik yapısı kullanılarak da keşfettirilebilir, etkinlik-3 bu bağlamda geliştirilebilir. 


\section{Kaynaklar}

Akdeniz, A. R., Yiğit, N., \& Kurt, Ş. (2002). Yeni fen bilgisi programı ile öğretmenlerin görüşleri. 5.Ulusal Fen Bilimleri ve Matematik Eğitimi Kongresi Bildiriler Kitabı, Cilt: 1, 400-406, ODTÜ, Ankara.

Altun, M. (2009). Eğitim fakülteleri ve lise matematik öğretmenleri için liselerde matematik öğretimi. (3. Bask1). Bursa: Aktüel Alfa Akademi.

Antohe, V. (2009). Limits of educational soft "GeoGebra" in a critical constructive review. Ann. Univ. Tibiscus Comp. Sci. Series VII, 4754.

Aydoğan, A. (2007). "Dinamik geometri yazılımlarının açık uçlu araştırmalarla birlikte altıncı sınıf düzeyinde çokgenler ve çokgenlerde eşlik benzerlik öğrenimine etkisi”. (Yayınlanmamış yüksek lisans tezi). ODTÜ, Ankara.

Baki, A. (1996). Matematik öğretiminde bilgisayar herşey midir? Hacettepe Üniversitesi Eğitim Fakültesi Dergisi, 12, 135-143.

Baki, A. (2002). Öğrenen ve öğretenler için bilgisayar destekli matematik. İstanbul: Ceren Yayın Dağıtım.

Baydaş, Ö. (2010). “Öğretim elemanlarının ve öğretmen adaylarının görüşleri ışı̆̆ında matematiköğretiminde Geogebra kullanımı”. (Yayınlanmamış yüksek lisans tezi). Atatürk Üniversitesi, Erzurum.

Baydaş, Ö., Göktaş, Y. \& Tatar, E. (2010). Öğretmen adaylarının bakışıyla Geogebra ile matematik öğretimi. 9.Ulusal Fen Bilimleri ve Matematik Eğitimi Kongresi, Dokuz Eylül Üniversitesi, İzmir.

Baykul, Y. (2009). İlköğretimde matematik öğretimi (6 8.Sınıflar). Ankara: Pegem Akademi.

Budak, S. (2010). "Çokgenler konusunun bilgisayar destekli öğretimin 6. sınıf öğrencilerinin akademik başarılarına ve bilgisayar destekli geometri öğretimine yönelik tutumlarına etkisi”. (Yayınlanmamış yüksek lisans tezi). Eskişehir Osmangazi Üniversitesi, Eskişehir.

Bukova Güzel, E. \& Alkan, H. (2005). Yeniden yapılandırılan ilköğretim programı pilot uygulamasının değerlendirilmesi. Kuram ve Uygulamada Eğitim Bilimleri, 5(2), 385-425.

Çepni, S. (2010). Araştırma ve proje çalışmalarına giriş. (5. Baskı). Trabzon.

Demir, V. (2010). “Cabri 3d dinamik geometri yazılımının, geometrik düşünme ve akademik başarı üzerine etkisi”. (Yayınlanmamış yüksek lisans tezi). Marmara Üniversitesi, İstanbul.

Dey, I. (1993). Qualitative data analysis: A user friendly guide for social scientists. London: Routledge.

Dikovic, L. (2009). Applications Geogebra into teaching some topics of mathematics at the college level, ComSIS (6).

Doğan, M. (2011). Bir dinamik matematik yazılımı: Geogebra. E. Karakırık (Ed.), Matematik eğitiminde teknoloji kullanımı içinde (ss.97 156), Ankara: Nobel Yayın Dağıtım.

Ekiz, D. (2009). Bilimsel araştırma yöntemleri (2. Baskı). Ankara: Anı yayıncılık.

Ersoy, Y. (2006). İlköğretim matematik öğretim programındaki yenilikler: amaç, içerik ve kazanımlar. İlköğretim Online, 5(1), 30-44. [Online]: http://ilköğretim online.org.tr adresinden 18 Ekim 2012 tarihinde indirildi.

Erüs, E. E. (2007). “Analitik geometri dersine eleştirel düşünme becerilerine dayalı öğretimin öğrenci erişi düzeyi ve kalıcılığına etkisi". (Yayınlanmamış yüksek lisans tezi). Hacettepe Üniversitesi, Ankara.

Gomes, A. S. \& Vergnaud, G. (2004). On the learning of geometric concepts using dynamic geometry software. Novas Technologias na Educaçao, V.2, Março, 2004.

Güven, B. (2002). “Dinamik geometri yazılımı Cabri ile keşfederek geometri öğrenme”. (Yayımlanmamış yüksek lisans tezi). KTÜ, Trabzon.

Güven, B. \& Karataş, İ. (2003). Dinamik geometri yazılımı Cabri ile geometri öğrenme: Öğrenci görüşleri. The Turkish Online Journal of Educational Technology, 2(2), 67-78. 
Hohenwarter, M. \& Jones, K. (2007). Ways of linking geometry and algebra: The case of Geogebra. Proceedings of the British Society for Research into Learning Mathematics, 27(3), 126-131.

Hohenwarter, M. \& Hohenwarter, J. (2011). Geogebra resmi kullanım kılavuzu (M. Doğan ve E. Karakırık, Çev.) Ankara: Nobel. (Original work published 2008).

Işık, A. \& Konyalığlu, A. C. (2005). Matematik eğitiminde görselleştirme yaklaşımı. Kazım Karabekir Eğitim Fakültesi Dergisi, 11, 462-471

Kabaca, T. (2006). “Limit kavramının öğretiminde bilgisayar cebiri sistemlerinin etkisi”. (Yayımlanmamış doktora tezi). Gazi Üniversitesi, Ankara.

Kağızmanlı, T.B. \& Tatar, E. (2012). Matematik öğretmeni adaylarının bilgisayar destekli matematik hakkındaki görüşleri: Türevin uygulamaları örneği. Kastamonu Eğitim Dergisi, 20(3), 897-912.

Karaaslan, G. (2013). "Geometri dersine yönelik dinamik geometri yazılımlarıla hazırlanan etkinliklerin öğrencilerin akademik başarısı ve uzamsal yetenekleri bağlamında incelenmesi”. (Yayınlanmamış yüksek lisans tezi). Marmara Üniversitesi, İstanbul.

Karakırık, E. (2011). Dinamik geometri ve Sketchpad ile geometri öğretimi. E. Karakırık (Ed.), Matematik eğitiminde teknoloji kullanımı içinde (s. 67-96), Ankara: Nobel Yayın Dağıtım.

Karakırık, E. ve Aydın, E. (2011). Matematik öğrenme nesneleri. E. Karakırık (Ed.), Matematik eğitiminde teknoloji kullanımı (s. 19 33), Ankara: Nobel Yayın Dağıtım.

Karakuş, Ö. (2008). "Bilgisayar destekli dönüşüm geometrisi öğretiminin öğrenci erişine etkisi”. (Yayınlanmamış yüksek lisans tezi). Eskişehir Osmangazi Üniversitesi, Eskişehir.

Kerpiç, A. \& Bozkurt, A. (2011). Etkinlik tasarım ve uygulama prensipleri çerçevesinde 7.sınıf matematik ders kitabı etkinliklerinin değerlendirilmesi. Mustafa Kemal Üniversitesi Eğitim Bilimleri Enstitüsü Dergisi, 8(16), 303-318.

Korucu, S. (2009). "Çokgenler konusunda karikatür ve bilgisayar destekli öğretim yöntemlerinin karşılaştırılması”. (Yayınlanmamış yüksek lisans tezi). Marmara Üniversitesi, İstanbul.

Kutluca, T. \& Birgin, O. (2007). Doğru denklemleri konusunda geliştirilen bilgisayar destekli öğretim materyali hakkında matematik öğretmeni adaylarının görüşlerinin değerlendirilmesi. GÜ Gazi Eğitim Fakültesi Dergisi, 27(2), 81-97.

M.E.B. Talim ve Terbiye Kurulu Başkanlığı (2010). Ortä̈ğretim Geometri Dersi 9 10. Sinıflar Öğretim Programi. Ankara: M.E.B.

M.E.B. Talim ve Terbiye Kurulu Başkanlığg (2011a). Ortaöğretim Matematik (9, 10, 11 ve 12. Sinıflar) Dersi Öğretim Programı \& Ortaöğretim Seçmeli Matematik (10, 11 ve 12. Sinıflar) Dersi Öğretim Programi, Ankara: M.E.B.

M.E.B. Talim ve Terbiye Kurulu Başkanlığı (2011b). Ortaöğretim Geometri Dersi 12. SınıfÖğretim Programı. Ankara: M.E.B.

M.E.B. Devlet Kitapları (2011c). İlköğretim Matematik 8 Ders Kitabı. Ankara: MEB.

M.E.B. Talim ve Terbiye Kurulu Başkanlığı (2013). Ortaöğretim Matematik Dersi (9, 10, 11 ve 12. Sinıflar) Öğretim Programi. Ankara: M.E.B.

Olkun, S. \& Toluk, Z. (2005). İlköğretimde etkinlik temelli matematik öğretimi, Anı Yayıncılık, Ankara.

Özmantar, M. F. \& Bingölbali, E. (2009). Etkinlik tasarımı ve temel tasarım prensipleri. M. F. Özmantar ve E. Bingölbali (Ed.), Matematiksel Zorluklar ve Çözüm Önerileri (s.313-348).

Patton, M. Q. (2002). Qualitative research \& evaluation methods. (3rd ed.). Thousand Oaks, CA: Sage Publications.

Taş, M. (2010). "Dinamik matematik yazılımı Geogebra ile eğrisel integrallerin görselleştirilmesi”. (Yayınlanmamış yüksek lisans tezi). İstanbul Üniversitesi, İstanbul. 
Uğurel, I. \& Bukova-Güzel, E. (2010). Matematiksel öğrenme etkinlikleri üzerine bir tartışma ve kavramsal bir çerçeve önerisi. Hacettepe Üniversitesi Eğitim Fakültesi Dergisi, 39, 333-347.

Uşun, S. (2004). Bilgisayar destekli öğretimin temelleri. (2. Baskı). Ankara: Nobel Yayın Dağıtım.

Yenilmez, K. \& Karakuş, Ö. (2007). İlköğretim sınıf ve matematik öğretmenlerinin bilgisayar destekli matematik öğretimine ilişkin görüşleri. Mehmet Akif Ersoy Üniversitesi Eğitim Fakültesi Dergisi, 8(14), 87-98.

Yıldırım, A. \& Şimşek, H. (2008). Sosyal bilimlerde nitel araştırma yöntemleri (7. basım). Ankara: Seçkin. 
